Biol Neonate 1989;55:I-III

\title{
Contents, Vol. 55, No. 6, 1989
}

\section{Foreword}

Girard, J 321

Sexual Differentiation of the Gonads and of the Reproductive Tract

Wilson, J.D 322

Endocrine Control of Fetal Growth

Browne, C.A.; Thorburn, G.D

An Update of Fetal and Placental Metabolism: Carbohydrate and Amino Acids

Battaglia, F.C 347

Solute and Water Transport across the Pulmonary Epithelium: A New Chapter in Lung Physiology Inaugurated by Alfred Jost

Strang, L.B 355

Initiation of Labour

Liggins, G.C 366

Thyroid Hormones and Nervous System Development

Timiras, P.S.; Nzekwe, E.U 376

Author Index 386

Subject Index 388 